\title{
FINANCIAL INCLUSION: A PANACEA FOR ATTAINING SUSTAINABLE DEVELOPMENT IN DEVELOPING COUNTRIES LIKE NIGERIA
}

\author{
Reuben Ogbe Osagie ${ }^{1, \mathrm{a}, *}$ \\ ${ }^{1}$ Business Administration Department, Faculty of Management Sciences, Lagos State University, \\ Lagos, Nigeria \\ areubenosagie@gmail.com \\ ${ }^{*}$ Corresponding author
}

Cite as: Osagie, R. O. (2020). Financial inclusion: A PANACEA for attaining sustainable development in developing countries like Nigeria, Ekonomicko-manazerske spektrum, 14(2), 1-11.

Available at: dx.doi.org/10.26552/ems.2020.2.1-11

Received: 10 February 2020; Received in revised form: 6 May 2020; Accepted: 18 May 2020; Available online: 12 August 2020

\begin{abstract}
The study "Financial Inclusion: A Panacea for Attaining Sustainable Development in Developing Countries like Nigeria" was embarked on by the researcher with the view of ascertaining whether financial inclusion of majority of citizens on part of the government can lead to sustainable development in line with the UN (2015) Sustainable Development Goal. The sub-variables under consideration were access to loans and credit facilities; and financial literacy for the independent variable financial inclusion and poverty reduction; gender equality for the dependent variable sustainable development. Cross-sectional descriptive research design was adopted by the researcher. The researcher used primary data to elicit information for this study. The population for the study was taken from six (6) communities selected from 6 Local Government Areas from the Lagos and Ogun States, with each state contributing 3 communities, respectively. A total of 750 questionnaires was distributed, with 125 questionnaires handed out to each respective community; 532 questionnaires were returned in a form usable for the study, amounting to $70.9 \%$ deemed valid to arrive at a valid conclusion. Content validity was adopted for this study. Reliability test was conducted using Cronbach Alpha, which returned 0.837, showing internal consistency of the research instrument. Descriptive statistics such as mean, simple percentage were used to analyze the demography of respondents while regression and Pearson correlation coefficients were used to analyze the data. The findings revealed that access to loans and credit facilities lead to poverty reduction in developing countries like Nigeria, and financial literacy is a prerequisite for ensuring gender equality in developing countries like Nigeria, with a $\mathrm{p}$ value of $0.000<0.05$, a correlation coefficient of 0.651 , an unstandardized coefficient of 1.204 (120.4\%). The results and findings were sufficient to assert that financial inclusion is indeed a panacea for attaining sustainable development in developing countries like Nigeria.
\end{abstract}

Keywords: credit and loans facilities, financial inclusion, financial literacy, gender equality, sustainable development

JEL Classification: M1, M10, M2, M21 
Financial inclusion: A PANACEA for attaining sustainable

development in developing countries like Nigeria

Author: Reuben Ogbe Osagie

\section{Introduction}

Achieving sustainable development has been a burning issue and frontline agenda of the United Nations, more so among least developed countries, less developed countries, landlocked developing, and small island developing countries of the world (UN, 2017). Sustainable development has been defined by the World Commission on Environment and Development (WCED) in the Brundtland Commission Report (1987) as the ability of the present generations to meet their own needs without compromising the ability of the future generations to meet their own needs. (Ranjula, 2019) The Sustainable Development Goals (SDGs) of the United Nations have been described as transformative, with the intention of eradicating poverty, improving the social, economic, and environmental conditions of people across all nations of the world irrespective of race, color, ethnicity, religion, financial status, etc. (UN, 2015) The United Nations has arrived at a resolution to eradicate all forms of poverty, including extreme poverty, and set the world on path of sustainable development and resilience; the member nations drew up a 17-point list of Sustainable Development Goals with an accompanying list of 167 targets on September 27, 2015. These set the tone for member nations to develop plans and policies in areas of critical importance to humanity and the planet. (UN, 2015)

The journey to the 17-point SDGs started back in 1970, when the Organization for Economic Co-operation and Development began focusing on three (3) pillars of development, namely economic, social, and environmental, with the development of Agenda 21 which stated in its paragraph 404 that "indicators of sustainable development needed to be developed to provide solid bases for decision-making at all levels and to contribute to a self-regulating sustainability of integrated environment and development systems". This was later adopted at the United Nations Conference on Environment and Development at Rio de Janeiro in 1992 by 183 governments of the member nations and was later re-affirmed at the World Summit in 2002 in Johannesburg, and in Rio de Janeiro in 2012 at the Rio +20 Summit. (Easterly, 2015)

Initially, sustainable development involved ensuring optimal consumption of goods and services by vast majority of the populace, but the United Nations at its World Summit at Johannesburg in 2002 and Rio de Janeiro in 2012 affirmed that its Sustainable Development Goals (SDGs) should include "ending all forms and dimensions of poverty, ensuring health coverage universally, reducing preventable deaths in relation to children, and maternal mortality before 2030, removing woman and girl child discriminations of all forms the world over, and achieving full employment and productivity for all women and men." Part of the Sustainable Development Goal agenda includes eradicating poverty, establishing socioeconomic and financial inclusion for all people, and protecting the environment. (Leeladhar, 2005)

Worldwide, financial inclusion has been seen as a complex instrument to help in the fight against unemployment, inequality, and impoverishment, in addition to wealth creation and transformation in people's welfare. The term financial inclusion, although it had existed before, increased in importance in the early $20^{\text {th }}$ century because of the relationship between impoverishment and financial exclusion discovered by researchers. (Bakari et al. 2019) The idea of financial inclusion has become essential in recent years, at the global and international level, for government establishments and non-governmental institutions alike, whose fundamental duty is ensuring an all-inclusive society, as defined in the Sustainable Development Goals, of most developing nations the world over. A recent World Bank report has shown that $50 \%$ of the world's adult population are estimated to be financially included globally; $92 \%$ of grownup people in developed and sophisticated nations have access to conventional financial services, $43 \%$ in Asia, 35\% in Latin America, and only 23\% in Africa, with Central Africa at the global geographical low of $7 \%$. Researchers have argued that the low 
level of financial inclusion in African sub-regions is due to the inferior income, ingestion driven economy, less investment, and depressed economic growth. (World Bank, 2017)

The blunt fact is that most people in the world still have difficulties in accessing sustainable financial services, be it in the form of savings deposit, credit, or insurance, in spite of the global efforts to ensure financial inclusiveness across all nations of the world; the greater challenge lies in addressing the confinement that omits people from participating in the financial sector the world over.

Financial inclusion has become a significant issue in developing countries like Nigeria, where many citizens are still not able to access basic financial services and formal financial institutions. The Nigerian government, like many of its counterparts in other developing nations, has tried many agendas, policies, and even strategies geared at increasing the financial inclusiveness of its people, but these are yet to yield the desired results; as financial inclusion increases, citizenry have more access to financial services to increase their consumption and engage in more prolific action. Technology, which is supposed to be able to bridge the gap for the financially excluded, has become a costly hurdle for business owners, private institutions, and even government agencies in third world countries and developing economies like Nigeria, and processing tailored solutions or investing in sophisticated financial programs has either proved impossible or resulted in too many failures.

Out of the over 200 million Nigerians of whom approximately 60\% represent adult population according to the World Bank report of 2018, only $25 \%$ have access to financial services (CBN reports). The bulk of Nigerian financially proactive and technologically understanding citizens are in the urban centers where economic activities are flourishing, while rural communities continue to face financial exclusion. (Ajide, 2014) Sanusi (2011) posited that the increase in the number of people being financially excluded from conventional financial systems is accountable for the advanced poverty in Nigeria. According to McKinsey (2014), Nigerians with access financial services amount to approximately $21 \%$ of the country's population, while Cyn-Young and Ragelio (2015) found that Nigeria ranked $135^{\text {th }}$ out of the 176 countries measured in terms of financial inclusion.

This is the rationale behind the researcher undertaking to investigate whether financial inclusion can serve as a panacea for attaining sustainable development goals in developing and third world countries.

\section{Objectives of the study and research hypotheses}

The general objective for this study is to examine financial inclusion as a panacea for attaining sustainable development in developing and third world countries using the data from local governments of Nigeria's Lagos and Ogun states. The specific objectives that will be pursued in line with the study's main objective are:

1. To examine whether access to loans and credit facilities reduces poverty in developing countries like Nigeria; and

2. To evaluate the relationship between financial literacy and gender equality in developing countries like Nigeria.

The following research hypotheses will be tested along with the objectives of the study in their null form.

Ho: There is no significant effect of access to loans and credit facilities on the reduction of poverty in developing countries like Nigeria

$\mathbf{H}_{0}$ : There is no significant relationship between financial literacy and gender equality in developing countries like Nigeria. 


\section{Literature review}

Financial inclusion extends beyond the boundaries of the financial sector to include other fields as well, and therefore requires a high-level conceptualization that includes national vision, confirms policy objectives that play a part in the wider definition of inclusion, and defines product attributes. The Central Bank of Nigeria (2012) defined financial inclusion as a situation where adult citizens have easy access to a broad range of financial products such as payments, savings, credits, insurance, and pensions, designed and provided to suit the needs of these adult citizens at affordable cost. Similarly, the Bank of Tanzania defined financial inclusion as regular use of financial services through payment infrastructures to manage cash flows and mitigate shocks, which are delivered by formal providers through a range of appropriate services with dignity and fairness.

Financial inclusion can thus be referred to as a state in which all working age adults have effective access to credit, savings, payments, and insurance from formal service providers. Effective access involves convenient and responsible service delivery, at a cost affordable to the customer and sustainable by the provider, with the result that financially included customers use formal financial services rather than existing informal options. Sarma (2008) defined it as the activity that guarantees ease of access, accessibility, and utilization of a formal financial system. Mbutor and Ibrahim (2013) were of the opinion that growing financial inclusion would improve the effectiveness of monetary policy in any country, but the coefficient of the number of bank branches in developing and low-income countries gives a wrong signal which can be explained by the fact that, by opening branches, banks pursue profits rather than financial inclusion as a policy objective. Mehar (2014) argued that financial inclusion can be reframed based on the process that ranges from opening of bank accounts to credit facilities and other financial services, such as financial advice.

Dr. Rangaranjan (2009) defined it as the process of ascertaining access to financial services, timely and sufficient credit when needed by assailable groups, such as the weaker sections and low-income groups, at an affordable cost, by mainstream financial institutions players. It must be noted that financial services do not involve banking products only, but also a host of other financial services like credit, insurance, and other types of equity products. The segment of the society unable to access timely credit and other financial services in appropriate form from formal sources are financially excluded, creating a concern for the policy maker. The three main elements of financial inclusion according to Leeladher (2005) are: having access to banking services; access to affordable and timely credit; and access to financial literacy programs that educate people about a healthy financial life.

Financial literacy according to CBN (2015) may be defined as the knowledge and skill possessed by individuals to manage their financial resources effectively to improve their living conditions. Similarly, Balatti (2007) believes financial literacy is the capacity to make judgments that are informed and decisions that are effective concerning management and utilization of money in real life situations. It gives financial service providers better understanding of their products, the risks associated with them, and their customers' needs. It entails trust, assurance, and contribution in the formal financial system. Financial literacy has become a burning issue in the pursuit of financial inclusion, financial stability, economic growth, and development. Inclusive growth in the economy can only be attained when majority of the adult population partakes in the financial sector. This can only be achieved when the populace has clear knowledge, understanding, and develops its ability to appraise financial products and services, as well as partake in the operations of the financial sector.

Vare and Scott (2007) opined that sustainable development is a process of changes, where resources are raised, the direction of investments is determined, the development of technology 
is focused and the work of different institutions is harmonized, thus the potential for achieving human needs and desires is increased as well. To Sterling (2010), sustainable development is a reconciliation of the economy and the environment on a new path of development that will enable the long-term sustainable development of humankind. From the above definitions it is obvious that improvement of human life is the paramount aim of sustainable development, whereas the particulars vary across geographical conditions, countries, regions, and differences in focus. The need for unification of priorities of sustainable development led the United Nations to develop the 17-point Sustainable Development Goals Agenda at its World Congress, the goals being: 1. No poverty; 2. Zero hunger; 3. Good health \& wellbeing; 4. Quality education; 5. Clean water \& sanitation; 6. Affordable \& clean energy; 8. Decent work \& economic growth; 9. Industry, innovation \& infrastructure; 10. Reduced inequalities; 11. Sustainable cities \& communities; 12. Responsible consumption \& production; 13. Climate action; 14. Life below water; 15. Life on land; 16. Peace, justice \& strong institutions; and 17. Partnerships for the goals.

Discrimination connotes an unfavorable treatment meted on the bases of sex and/or race. It is an impediment to actualization of the objectives of equality, development, and peace. Discrimination is a practice of inequality and has become an issue for women the world over. It prevents free participation of women in the society, with the related negative impact on their psychological wellbeing. Women, who form half of the world's population, are being discriminated against, directly or indirectly, in various aspects of their lives; although this varies across countries, religions, societies, or ethnicities, it denies women opportunities, privileges, or rewards specifically because of their gender. (Ranganran, 2009)

Mahdavi and Horton (2012) in their examination of female alumni of women's liberal arts colleges found that their financial literacy was very low, even though they were otherwise well educated. This was like the findings of Lusardi, Mitchell, and Curto (2010) that women irrespective of age and social status are less financially knowledgeable than their male counterparts. Aladekomo (2004) also found in his study of Nigeria's education policy and entrepreneurship that female education faced discrimination based on cultural bias that favors males due to power and privilege issues. He argued that a widespread patriarchal system occurs in social organization across Africa, including Nigeria, where there is preference for male over female children. In his study, de Bassa Scheresberg (2013) found a positive correlation between consumers' financial literacy and their individual probability to engage in precautionary savings. This shows a link between financial literacy, savings, consumers' investment decisions of consumers and their behavior with respect to financing. Similarly, Lusardi and Tufano (2015) found that people in the US who exhibit low levels of financial literacy make use of high-cost borrowing methods and pay higher transaction costs and fees. In their findings, Disney and Gathergood (2013) corroborated the findings of Lusardi and Tufano (2015) by revealing that low levels of financial literacy are associated with excessive utilization of high-cost credit such as payday loans or mail order catalogue debt. Ogunsakin and Fawehinmi (2017) in their study of financial inclusion as an effective policy tool of poverty alleviation: a case of Ekiti State, Nigeria adopted simple random sampling technique to sample 180 adult respondents, using questionnaires to solicit response. Descriptive statistics and multinomial logits were used to empirically analyze the results obtained. Their findings revealed that poverty rate was higher among women, with women accounting for $58 \%$ and men for $42 \%$ of the poor in the state. The findings also included that the number of commercial banks used across the three senatorial districts of the state was extremely low. Evans (2016) modeled the impact of financial inclusion in Africa and found that financial inclusion is not an evidential motivation of monetary policy effectiveness while monetary policy effectiveness does promote financial inclusion. 
Furthermore, a study conducted by Chitokwindo, Mago, and Hofisi (2014) examined financial inclusion in Zimbabwe utilizing qualitative research methodology exploratory in nature. Their findings revealed that financial exclusion comes in different forms and is responsible for poverty and inequality in rural areas; they recommend developing the rural banking sector to mobilize local resources and develop businesses. Similarly, Nwankwo and Nwankwo's (2014) investigation of sustainability of financial inclusion of rural dwellers in Nigeria using descriptive study and content analysis observed that sustainability of financial inclusion of rural dwellers in Nigeria is, much like in most countries of the region, a mainstream means of achieving economic growth, due to increase in use of mobile phones in Sub-Saharan Africa which forms the foundation for a revolution in the mobile money transfer system.

\section{Methodology}

The study adopted a cross-sectional descriptive research design, with questionnaires structured to contain closed ended questions using a 6-point Likert-type scale measurement rating of Strongly Agree (6), Agree (5), Partially Agree (4), Partially Disagree (3), Disagree (2), and Strongly Disagree (1) points, respectively, intended at capturing reality in quantitative terms. The population of study was drawn from six (6) different communities selected from six (6) local governments in two (2) states in Nigeria, namely the Lagos State and the Ogun State, due to their proximity and their right mix of class structure (the extremely poor, the poor, the middle class, the elites, the wealthy and affluent) inherent in any developing country of the world. Each state contributed three (3) communities from three (3) local governments, respectively, for this study as indicated in the population table below. The sample size for this research was drawn using the convenience sampling technique, the researcher selected 125 respondents from each community listed in the table below.

A reliability test was conducted using Cronbach Alpha to ensure internal consistency and stability of the measuring instruments used by the researcher and returned a Cronbach Alpha coefficient of 0.837 as shown below, which amounts to acceptable reliability and is an indication that the test results were consistent over time. Regression analysis and correlation coefficient were employed to analyze data, while sample percentage and mean were used for demographic analysis of respondents.

Table 1: Reliability statistics

\begin{tabular}{ll}
\hline Reliability Statistics & \\
\hline Cronbach's Alpha & No of Items \\
.837 & 12 \\
\hline
\end{tabular}

Source: Author's computation

Table 2: List of Communities from which Population and Sample was drawn

\begin{tabular}{llll}
\hline Community & Local Government Area & State & $\begin{array}{l}\text { No of Questionnaires } \\
\text { Distributed }\end{array}$ \\
\hline Amikanle Town & Oke-Odo LCDA & Lagos & 125 Copies \\
Iba Town & Ojo & Lagos & 125 Copies \\
Ikola Community & Alimosho & Lagos & 125 Copies \\
Aiyepe Town & Odogbolu & Ogun & 125 Copies \\
Oru Town & Ipokia & Ogun & 125 Copies \\
Igbesa & Ado-Odo/Ota & Ogun & 125 Copies \\
Total & & & 750 Copies \\
\hline Source: Field survey, (2019) & & &
\end{tabular}


Table 3: Number of Commercial Banks, or Micro-Finance Banks in Each Community

\begin{tabular}{lll}
\hline Community & No. of Commercial Banks & No of Micro-Finance Banks \\
\hline Amikanle Town & None & None \\
Iba Town & None & 1 \\
Ikola Community & None & 1 \\
Aiyepe Town & None & 1 \\
Oru Town & None & 1 \\
Igbesa Town & 1 & None \\
Source: Field survey, (2019) &
\end{tabular}

Table 3 shows availability of financial institutions such as commercial banks and/or microfinance banks in each of these communities that provide financial services or financial instruments to the residents who mostly fall within the lower echelon in the class structure and are mostly craftsmen, petty traders, market men and women, etc.

\section{Data presentation and Analysis}

Table 4: Demography of Respondents

\begin{tabular}{|c|c|c|c|c|}
\hline & Frequency & Percent & Valid Percent & Cumulative Percent \\
\hline \multicolumn{5}{|r|}{$x_{1}$} \\
\hline M & 248 & 46.6 & 46.6 & 46.6 \\
\hline $\mathrm{F}$ & 284 & 53.4 & 53.4 & 100.0 \\
\hline Total & 532 & 100.0 & 100.0 & \\
\hline \multicolumn{5}{|l|}{ Age } \\
\hline $21-30$ & 120 & 22.6 & 22.6 & 22.6 \\
\hline $31-40$ & 219 & 41.1 & 41.1 & 63.7 \\
\hline $41-50$ & 112 & 21.1 & 21.1 & 84.8 \\
\hline 51-above & 81 & 15.2 & 15.2 & 100.0 \\
\hline \multirow{2}{*}{\multicolumn{5}{|c|}{ Marital Status }} \\
\hline & & & & \\
\hline Single & 176 & 33.1 & 33.1 & 33.1 \\
\hline Married & 310 & 58.3 & 58.3 & 91.4 \\
\hline Divorced & 28 & 5.2 & 5.2 & 96.6 \\
\hline Widowed & 18 & 3.4 & 3.4 & 100.0 \\
\hline Total & 532 & 100.0 & 100.0 & \\
\hline \multicolumn{5}{|l|}{ Education } \\
\hline Non & 23 & 4.3 & 4.3 & 4.3 \\
\hline Primary & 240 & 45.1 & 45.1 & 49.4 \\
\hline Secondary & 183 & 34.4 & 34.4 & 83.8 \\
\hline Tertiary & 86 & 16.2 & 16.2 & 100.0 \\
\hline Valid Total & 532 & 100.0 & 100.0 & \\
\hline Employment Status & 69 & 13.0 & 13.0 & 13.0 \\
\hline Unemployed & 156 & 29.3 & 29.3 & 42.3 \\
\hline $\begin{array}{l}\text { Petty Trader/Craftmen } \\
\text { Transporter/Street Vendor }\end{array}$ & $\begin{array}{l}150 \\
105\end{array}$ & 19.7 & 19.7 & 62.0 \\
\hline $\begin{array}{l}\text { Public/Private Sector } \\
\text { employee }\end{array}$ & 137 & 25.8 & 25.8 & 87.8 \\
\hline Small Business owner & 65 & 12.2 & 12.2 & 100.0 \\
\hline Valid Total & 532 & 100.0 & 100.0 & \\
\hline
\end{tabular}

Source: Field Survey, (2020)

\section{Demographic attributes of respondents}

The table above shows the spread of respondents based on their demographic attributes. Sex distribution shows that 248 out of the 532 respondents representing $46.6 \%$ are male while the 
remaining 284 respondents representing $53.4 \%$ are female. This indicates that there are more females than males in the study's population. The age distribution shows a spread of 120 respondents, or $22.6 \%$, between the ages of $21-30,219$ respondents, or $41.1 \%$, between the ages of $31-40,112$ respondents, or $21.1 \%$, between the ages of $41-50$, and 81 respondents, or $15.2 \%$, older than 50 years of age. The distribution in terms of marital status showed that 176 respondents, or $33.1 \%$, were single, 310 respondents, or $58.3 \%$, were married, 28 respondents, or $5.2 \%$ were divorced, and further 18 respondents, or $3.4 \%$, were widowed. The education distribution displayed showed 23 respondents, or $4.3 \%$, had no formal education, 240 respondents, or $45.1 \%$, had primary education alone, 183 respondents, or $34.4 \%$, attained secondary education, and 86 respondents, or $16.2 \%$, had tertiary level education. The employment status revealed that 69 respondents, or 13\%, were unemployed; 156 respondents, or $29.3 \%$, were engaged in petty trading and/or craftsmanship; 105 respondents, or $19.7 \%$, were either street vendors or worked in transport as commercial bus drivers, conductors, or as part of park tours; 137 respondents, or $25.8 \%$, were officially employed in either the public sector or private organizations, and 65 respondents, or $12.2 \%$, owned small businesses. The summary of the demographic distribution revealed that the study's population was predominantly female, between the ages of 31-40, married, had formal primary level education, and operated mainly in the informal sector of the economy.

\section{Results}

Hypothesis 1: There is no significant effect of access to loans and credit facilities on the reduction of poverty in developing countries like Nigeria.

Table 5: Model Summary ${ }^{b}$

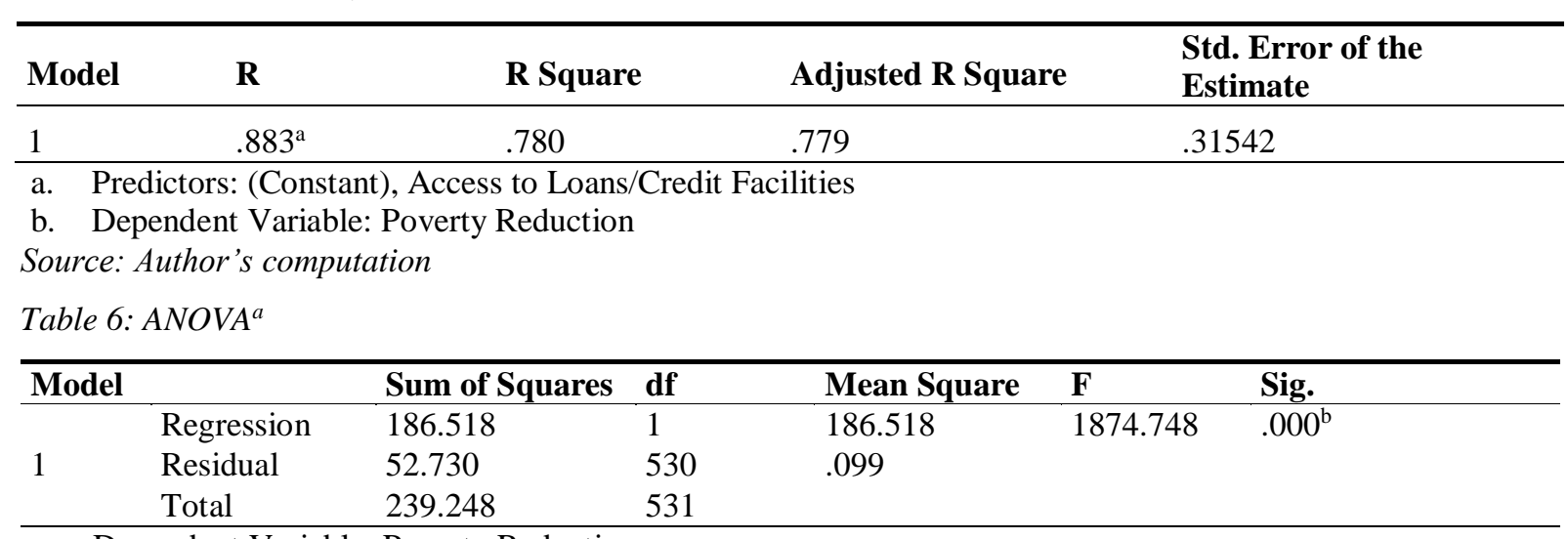

a. Dependent Variable: Poverty Reduction

b. Predictors: (Constant), Access to Loans/Credit Facilities

Source: Author's computation

Table 7: Coefficients ${ }^{a}$

\begin{tabular}{lllllll}
\hline Model & & \multicolumn{2}{c}{ Unstandardized Coefficients } & $\begin{array}{l}\text { Standardized } \\
\text { Coefficients } \\
\text { Beta }\end{array}$ & t & Sig. \\
\hline \multirow{2}{*}{$\begin{array}{l}\text { B } \\
1\end{array}$} & $\begin{array}{l}\text { (Constant) } \\
\text { Access to } \\
\text { Loans/Credit } \\
\text { Facilities }\end{array}$ & -.305 & .078 & & -3.893 & .000 \\
& & 1.204 & .028 & .883 & 43.298 & .000 \\
\hline
\end{tabular}

Dependent Variable: Poverty Reduction

Source: Author's computation 
The above tables are results of the regression analysis conducted on questions 1, 2, 3, 4 and 5 in the questionnaire. The Model summary table reveals that the variation in the dependent variable Poverty Reduction with an $\mathrm{R}^{2}$ value of $0.78(78 \%)$ can be explained by the constant Access to Loans/Credit Facilities.

The ANOVA table above reveals the assessment of statistical significance of the dependent variable (Poverty Reduction) using the $\mathrm{F}$ value and the $\mathrm{P}$ value in the table to determine the acceptability or rejection of the null hypothesis "There is no significant effect of access to loans and credit facilities on the reduction of poverty in developing countries like Nigeria". The F value returned an $F_{\text {observed }}(1874.748)>F_{\text {critical }}(3.85)$ and the $P$ value returned a $\mathrm{P}_{\text {observed }}(0.000)<\mathrm{P}_{\text {critical }}(0.05)$. This indicates that the regression model statistically significantly predicts that Access to Loans and Credit Facilities influences poverty reduction, therefore the null hypothesis is rejected.

The Coefficient table above shows the contribution of the constant Access to Loans and Credit Facilities to the dependent variable Poverty Reduction. The study undertakes to compare the contribution of the independent variable Access to Loans and Credit Facilities using the beta coefficient which returned a value of 1.204 (120.4\%) in the unstandardized coefficient. This indicates that Access to Loans and Credit Facilities has a positive and statistically significant effect of $120.4 \%$ increase in Poverty Reduction in Nigeria.

Hypothesis 2: There is no significant relationship between financial literacy and gender equality in developing countries like Nigeria.

Table 8: Correlations

\begin{tabular}{llll}
\hline & & Financial Literacy & Gender Discrimination \\
\hline \multirow{3}{*}{ Financial Literacy } & Pearson Correlation & 1 & $.651^{* *}$ \\
& Sig. (2-tailed) & & .000 \\
& $\mathrm{~N}$ & 532 & 532 \\
Gender Equality & Pearson Correlation & $.651^{* *}$ & 1 \\
& Sig. (2-tailed) & .000 & \\
& $\mathrm{~N}$ & 532 & 532 \\
\hline
\end{tabular}

**. Correlation is significant at the 0.01 level (2-tailed).

Source: Author's computation

The correlation table above is the result of a test applied to questions 6-10 in the questionnaire which reveals that there is a perfect positive relationship between financial literacy and gender equality in developing countries like Nigeria as obtained by the Pearson correlation of $0.651(65.1 \%)$. The significant 2-tailed test result shows that P: $0.000<0.05$ which is the study's standard alpha value. This shows that the study highly significantly predicts that financial literacy can help improve gender equality in developing countries like Nigeria by $65.1 \%$, although other variables will be needed to totally eradicate gender discrimination from the world.

\section{Discussion of Findings}

The findings from Hypothesis 1 were obtained using a regression analytical tool on SPSS and revealed that the constant Access to Loans and Credit Facilities contributes $78 \%$ to the variation of the dependent variable Poverty Reduction. The findings also revealed that there is a statistically significant "effect of access to loans and credit facilities on poverty reduction in Nigeria" as a result of the $P$ value of $.000<0.05$ and a $F_{\text {observed }} 1874.748>F_{\text {critical }} 3.85$ and a value of 1.204 in the unstandardized coefficient, meaning that Access to Loans and Credit Facilities has a $120.4 \%$ effect on Poverty Reduction in developing countries like Nigeria; this suffices to 
reject the null hypothesis and assert that "Access to loans and credit facilities has a statistical significant effect on Poverty reduction in developing countries like Nigeria". This finding is consistent with what Bakari et al. (2019) found in their study conducted on "an examination of the impact of financial inclusion on poverty reduction: an empirical evidence from Sub-Saharan Africa, where they examined 49 sub-Saharan countries using a static panel data model to analyze data and found that financial inclusion is a viable tool for a poverty reduction strategy in Sub-Saharan African countries, and that of Koulibali and Yogo (2016) in their study of the effect of financial services on poverty reduction in developing countries using the random and fixed effect model. They revealed that an improved access to financial services significantly reduces poverty, especially in countries with macroeconomic instability.

The findings from Hypothesis 2 were obtained using Pearson product-moment correlation coefficient on the null hypothesis "There is no significant relationship between financial literacy and gender equality in developing countries like Nigeria". The data analysis returned a value of 0.651 and a $\mathrm{P}: 0.000<0.05$, indicating that financial literacy has a $65.1 \%$ positive significant correlation with gender equality in developing countries like Nigeria. It indicates that when citizens of developing countries like Nigeria are financially literate, there is a $65.1 \%$ possibility of closing the gender inequality gap ravaging such countries. This finding is consistent with the findings of Mahdavi and Horton (2012) in their examination of female alumni of women's liberal arts colleges in the U.S., which found that their financial literacy was very low, even though they were otherwise well-educated; and that of Ogunsakin and Fawehunmi (2017) in their study of financial inclusion as an effective policy tool of poverty alleviation: a case of Ekiti State, Nigeria, where they adopted simple random sampling technique to a sample of 180 adult respondents, using questionnaires to solicit response. Descriptive statistics and multinomial logits were used to empirically analyze the results obtained. Their findings revealed that poverty rate was higher among women, with women accounting for $58 \%$ and men for $42 \%$ of the state's poor.

\section{Conclusion}

The indicators used by the researcher to measure the variables under consideration returned values that were both positive and statistically significant (P: $0.000<0.05 ; \mathrm{F}$ : $\mathrm{F}_{\text {observed }} 1874.748>\mathrm{F}_{\text {critical }} 3.85$; unstandardized coefficient of 1.204 and a correlation of 0.651 ); these results are sufficient to assert and conclude that "Financial Inclusion is a Panacea for attaining Sustainable Development in Developing Countries like Nigeria". If the government, its agencies, and machineries of government are sincere and vigorously pursue financial inclusion of their citizens by not merely defining and making policies of financial inclusion but rather also ensure their strict implementations and follow-up, sustainable development of the economy will be attainable, in line with the United Nations' Sustainable Development Goals, as will be lifting the more than 80 million Nigerian citizens living in abject poverty according to the Nigerian Bureau of Statistics report of 2020 out of these conditions.

\section{References}

Ajide, F. M. (2014). Financial inclusion and rural poverty reduction: evidence from Nigeria. Journal of Emerging Trends in Economics and Management Sciences, 3(2).

Aladekomo, O.F. (2004). Nigeria education policy and entrepreneurship. Journal of Social Science, 9(2), 75-83.

Bakari, I. H., Dongs, M., Idi, A., Hedima, J. E., Wilson, K., Babayo, H., \& Ibrahim, Y. (2019). An examination of the impact of financial inclusion on poverty reduction: An empirical evidence from Sub-Saharan Africa. International Journal of Scientific and Research Publications, 9(1), 239-252. 
Balatti, J. (2007). Financial literacy and social networks-what's the connection? Presentation at the Adult Learning Australia National Conference, Cairns.

Central Bank of Nigeria (2012). National Financial Inclusion Strategy Report.

Central Bank of Nigeria (2015). National Financial Literacy Framework.

Chitokwindo, S., Mago, S., \& Hofisi, C. (2014). Financial inclusion in Zimbabwe: A contextual overview. Mediterranean Journal of Social Sciences, 5(20), 414-423.

Cyn-Young, T., \& Rogelio, R. (2015). Financial inclusion, poverty and income inequality in developing Asia. ADB Economic Working Paper Series, no. 426.

de Bassa Scheresberg, C. (2013). Financial literacy and financial behavior among young adults: evidence and implications. Numeracy, 6(2).

Disney, R., \& Gathergood, J. (2013). Financial literacy and consumer credit portfolios. Journal of Banking \& Finance 37(7), 2246-2254.

Easterly, W. (2015). The Trouble with the sustainable development goals, Current History.

Koulibali, A., \& Yogo, U. T. (2016). Access to Financial Services and Working Poverty in Developing Countries. New York: Marrauntck Cornec.

Leeladhar, V. (2005). Taking Banking Services to the Common Man: Financial Inclusion Commemorative Lecture by Deputy Governor Reserve Bank of India, Ernakulam.

Lusardi, A, Mitchell, O. S., \& Curto, V. (2010). Financial literacy among the young. Journal of Consumer Affairs, 44(2), 358-380.

Lusardi, A., \& Tufano, P. (2015). Debt literacy, financial experiences, and over-indebtedness. Journal of Pension Economics \& Finance, 14(4), 332-368.

Mahdavi, M., \& Horton, N. (2012). financial literacy among educated women: Room for improvement. Unpublished.

Mbutor, M. O. and Ibrahim A. U. (2013). The impact of financial inclusion on monetary policy in Nigeria. Journal of Economics and International Finance, 5(8), 318-326.

McKinsey Global Institute (2014). Nigeria's Renewal: Delivering Inclusive Growth in Africa's largest Economy. Mckinsey Global Institute.

Mehar, L. (2014). Financial inclusion in India. Innovative Journal of Business and Management 3(4), 4-46.

Nwankwo, O., \& Nwankwo, G. (2014). Sustainability of financial inclusion to rural dwellers in Nigeria: Problems and way forward. Research Journal of Finance and Accounting, 5(5), 24-31.

Ogunsakin, S., \& Fawehinmi, F. O. (2017). Financial Inclusion as an Effective Policy Tool of Poverty Alleviation: A Case of Ekiti State. IOSR Journal of Economics and Finance, 8(4), 01-10.

Ranganran, C. (2009). Report of the Committee on Financial Inclusion India.

Ranjula, B. S. (2017). A critical analysis of the sustainable development goals. Handbook of Sustainability Science and Research, World Sustainability Series, 1-20.

Sanusi, L. S. (2011). Financial inclusion for accelerated micro, small and medium enterprises development: The Nigerian perspective. Paper presented at the 2011 Annual Microfinance and Entrepreneurship Awards.

Sarma, M. (2008). Index of financial inclusion: India council for research on international economics relations. Indian Council: New Delhi, India.

Sterling, S. (2010). Learning for resilience, or the resilient learner? Towards a necessary reconciliation in a paradigm of sustainable education. Environmental Education Research, 16, 511-528.

United Nations (2015). Global Sustainable Development Report. 2015 edition, New York.

United Nations (2017). Financial Literacy Report. 2017 edition. New York.

Vare, P., \& Scott, W. (2007). Learning for a change exploring the relationship between education and sustainable development. Journal of Education for Sustainable Development, 1, 191-198.

World Bank, (2017). Global Financial Development Report 2016: Financial Inclusion. Washington, DC. Available online [http://data.worldbank.org/datacatalog/financial_inclusion_.] 